\title{
Infection and amniotic aspiration of middle ear in stillbirths and neonatal deaths
}

\author{
D. J. DESA \\ From the Department of Pathology, McMaster University, Hamilton, Ontario, Canada
}

\begin{abstract}
deSa, D. J. (1973). Archives of Disease in Childhood, 48, 872. Infection and amniotic aspiration of middle ear in stillbirths and neonatal deaths. The middle ear cavities of 130 infants (36 stillbirths and 94 neonatal deaths) were studied at necropsy. In 56 cases the middle ear cavities were normal and free of extraneous debris (clear group); in 55 cases aspirated amniotic debris was seen (aspiration group); in 17 cases there was frank otitis media; and the 2 remaining cases had mucoid debris in the middle ear.

Aspirated debris in the middle ear was seen commonly in infants of over 28 weeks' gestation who had suffered from intrapartum asphyxia, and was usually associated with evidence of pulmonary aspiration of amniotic squames. Most of these infants were stillborn or had died in the first 2 days of postnatal life, but amniotic debris persisted for a longer period in some, and in 8 cases it had excited a foreign body histiocyte reaction.

The 17 cases with otitis media could be divided into two groups on the basis of middle ear findings: 11 cases with an admixture of amniotic debris and purulent exudate (P/A group) and 6 with purulent exudate only. The P/A group showed many clinical features in common with the infants of the aspiration group, with a high incidence of pregnancy complications and of need for prolonged ventilation.

All 17 cases with otitis media had evidence of infection elsewhere, including pneumonia (12) and meningitis (6). In 13 of the 14 cases with positive bacteriology, the organisms cultured were Gram-negative (Esch. coli or Pseudomonas aeruginosa).

It is argued that amniotic debris may be aspirated into the middle ear in asphyxiated babies and this may explain some of the unusual metaplastic changes noted in the epithelium of the middle ear cavities. Furthermore, stagnant amniotic debris may become secondarily infected by organisms, particularly if the infant requires ventilation.
\end{abstract}

While infections of the middle ear are known to be common in older children, relatively little attention has been paid to similar infections occurring in newborn infants. This is surprising since it has been shown by many writers that middle ear infections are common in this age group (Benner, 1940; Allen, Morison, and Rutherford, 1946; McLellan et al., 1962).

Earlier random examinations of the middle ear cavities in 28 stillbirths and newborn infants have shown that, for practical purposes, the findings in both middle ear cavities were identical. The present paper reports the results of a series of examinations of the middle ear cavities in stillbirths

Received 26 March 1973. and in neonatal deaths occurring within the first 28 days of life.

\section{Materials and methods}

The material was collected by the author from the Department of Pathology, Radcliffe Infirmary, Oxford. 130 pairs of middle ear cavities were studied over a period of 27 months in as nearly a consecutive series of necropsies as possible.

The left middle ear cavity was examined using the procedure described by Morison (1970). Smears of any fluid or exudate present were taken, and whenever purulent exudate was present bacteriological samples were taken for culture. The petrous temporal bone on the right side was dissected away from the skull so as to include the terminal portion of the external auditory canal and the tympanic membrane in continuity with the 


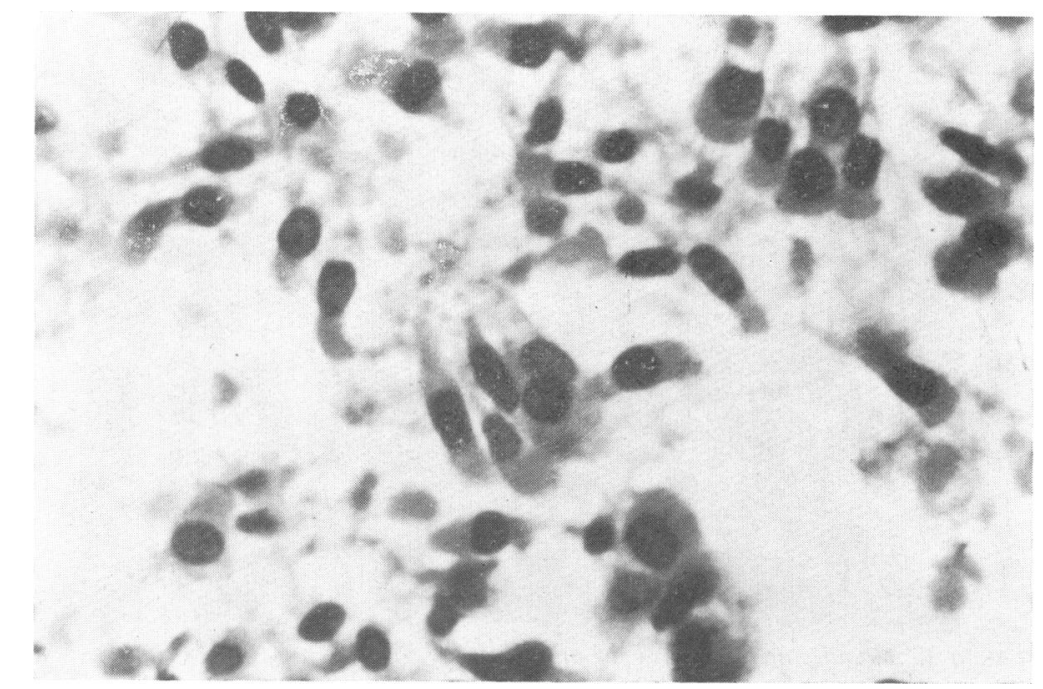

Fig. 1.-A high-power view of desquamated columnar epithelial cells in the otherwise 'clear' middle ear cavity of a stillborn infant. (Haematoxylin and eosin. $\times 1163$.

middle ear cavity. The specimen was fixed intact in formol saline for a week and then decalcified in either Gooding and Stewart's or Perenyi's fluid (Culling, 1963). After decalcification the specimen was sliced in a horizontal plane through the tympanic membrane. After embedding in paraffin, sections were cut and stained with haematoxylin and eosin and, where appropriate, by Gram's method.

Of a total of 130 cases studied, 36 were stillborn, 74 died within the first 7 days of life, and the remaining 20 died between 8 and 28 days. The details of any complications of pregnancy and/or postnatal life were available from the clinical notes, and any lesions found at necropsy were noted.

\section{Results}

Contents of middle ear cavity. In 56 cases the middle ears were either free of fluid or contained a small amount of clear fluid containing a few desquamated columnar epithelial cells (Fig. 1). These cases will be referred to as the 'clear' group. In one infant (aged 27 days) a small area of squamous metaplastic epithelium with a moderate stromal mononuclear infiltrate was present on histological examination (Fig. 2).

In 55 cases the middle ears contained amniotic debris, often with frank meconium and with

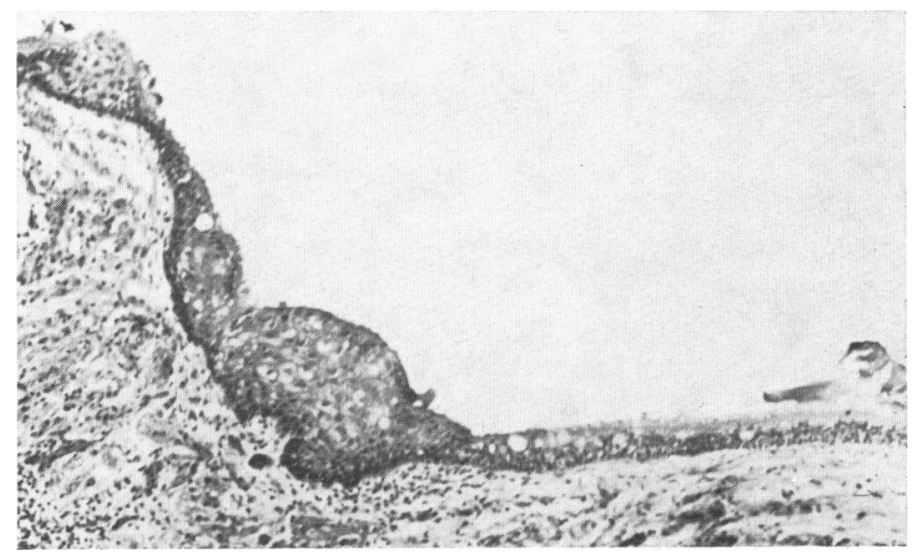

Fig. 2.-Area of metaplastic squamous epithelium with a moderate mononuclear stromal inflammatory infiltrate in an otherwise 'clear' middle ear, in a male aged 27 days. (H. and $E . \quad \times 381$. 


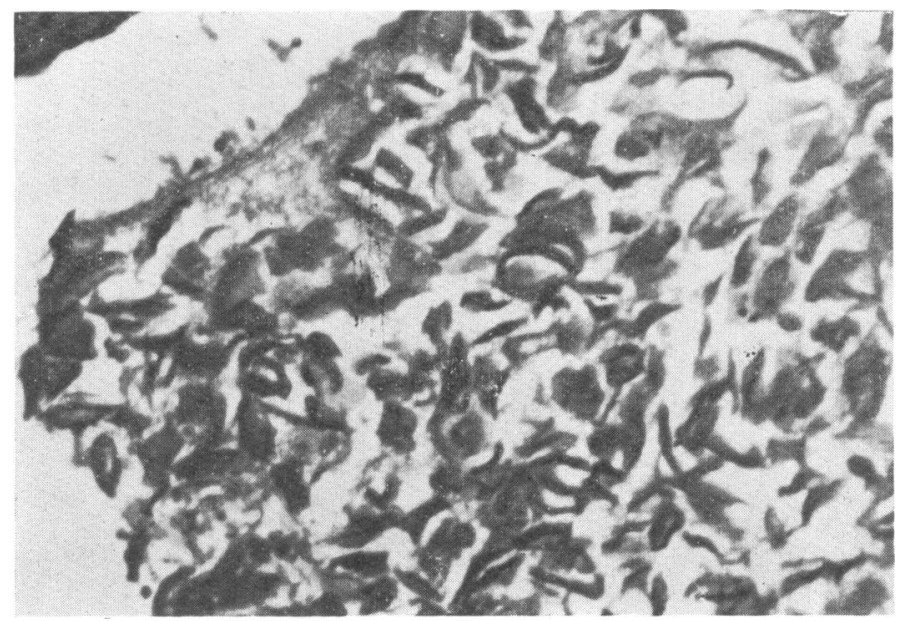

FIG. 3.-Aspirated amniotic squames and debris in the middle ear of a female infant aged 5 days.

(H. and $E . \quad \times 254$.

meconium-staining of the underlying mucosa (Fig. 3). These cases will be referred to as the 'aspiration' group. In 8 of these cases 'foreign body' giant cells and histiocytes could be seen engulfing the debris.

In 17 cases an obvious purulent exudate was noted in the middle ear, the 'otitis media' group. In 11 of these cases histological examination revealed an admixture of amniotic debris with leucocytes (Fig. 4), and this subgroup will be designated as the ' $\mathrm{P} / \mathrm{A}$ ' group. In all 17 cases there was evidence of an interstitial reaction within the lamina propria characterized by capillary dilatation, interstitial polymorphonuclear leucocytic exudate associated with mucosal necrosis and often with haemorrhage (Fig. 5). This combination of changes was not seen in any of the cases in either the 'clear' or 'aspiration' groups. In 11 older infants, scattered areas with dense interstitial mononuclear inflammatory cells admixed with polymorphonuclear leucocytes were seen (Fig. 6).

Numerically the least important group consisted of 2 cases where small amounts of mucoid debris

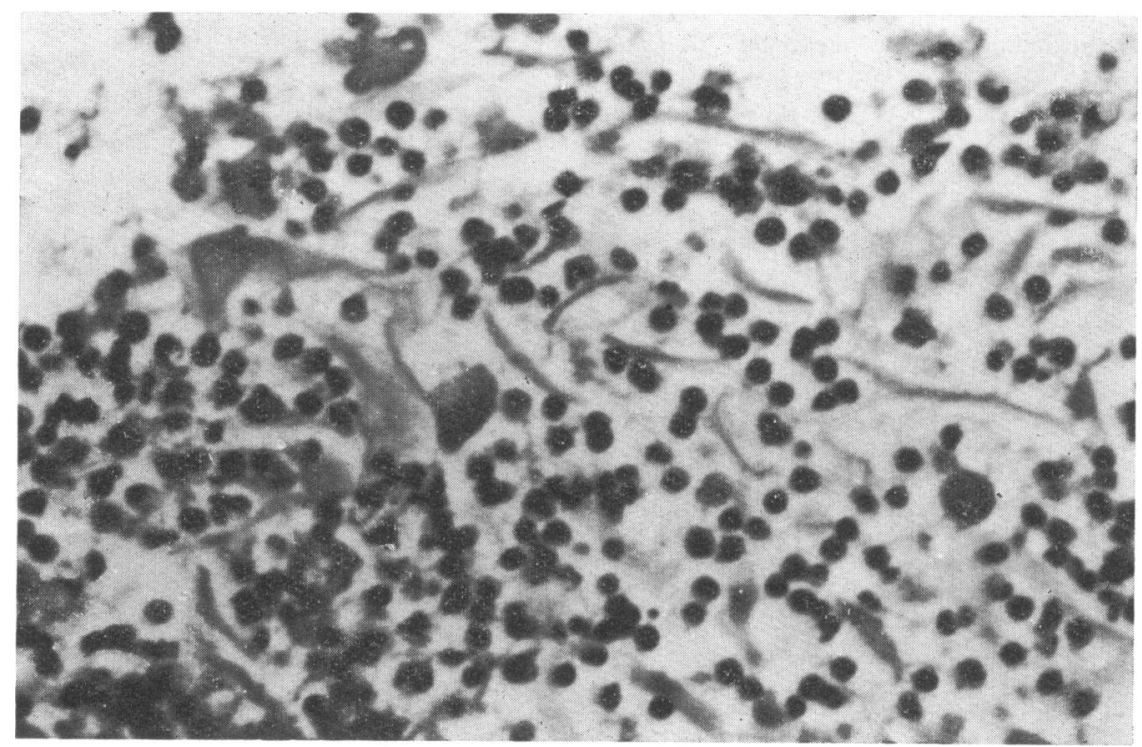

Fig. 4.-An admixture of purulent exudate and amniotic debris from Case 4 of Table. (H. and E. $\times 490$. 


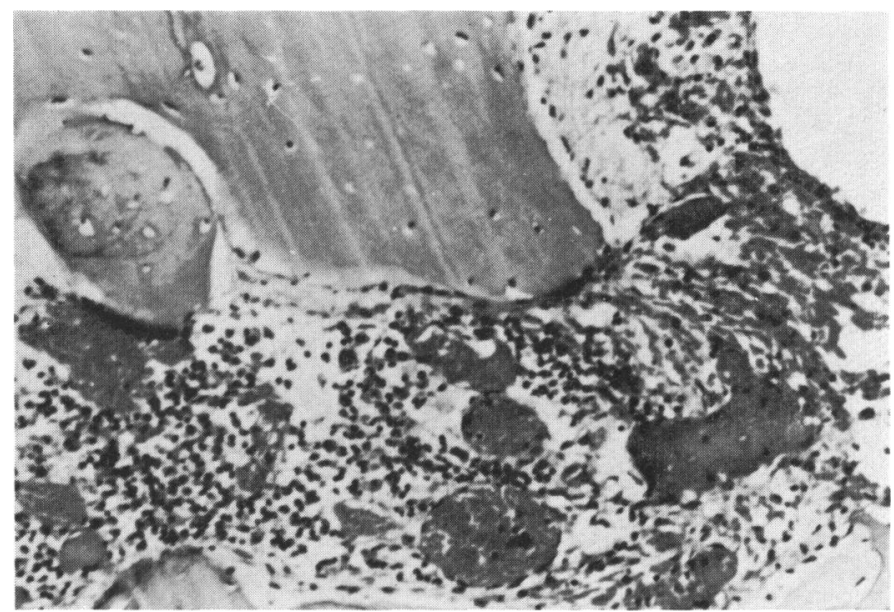

FIG. 5.-Stromal capillary dilatation and interstitial inflammatory response. (Same case as Fig. 4.) (H. and E. $\times 254$.)

with desquamated columnar epithelial cells were present. They will be described in subsequent sections as the 'mucoid' group. In one case small nodular epithelial protrusions were seen. They occurred in areas where cuboidal epithelial cells were apparently heaped up around lamellar particles of debris, and the changes were similar to 'drusen' seen in the eye (Fig. 7).

In none of the 130 cases was there any convincing evidence of labyrinthitis.

Sex. There were 81 male and 49 female infants in the series. The ratio among the 20 older infants in this series was 12 males to 8 females $(1 \cdot 7: 1)$. These figures were not significantly different from each other, and reflect the greater mortality among males in this age group.

Age. In Fig. 8 the percentage incidence of the findings in the series is analysed according to the age of the infants. It can be seen that while amniotic debris is common in the stillbirths and in infants dying in the first 2 days of life, it may still be present in some older infants. Otitis media, however, was

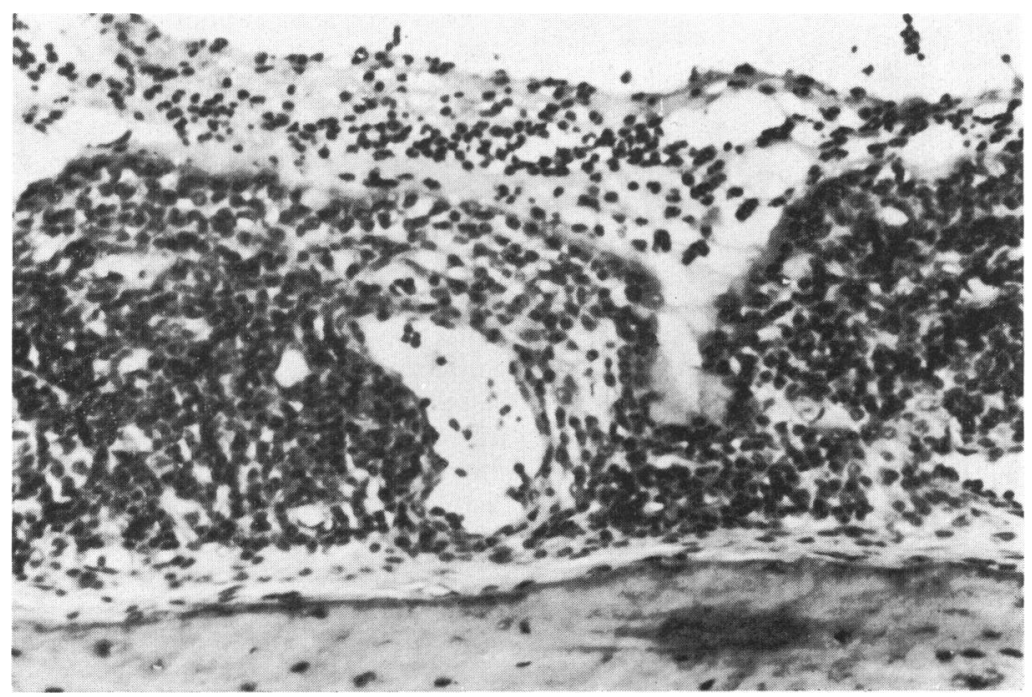

FIG. 6.-Pronounced mononuclear inflammatory cell reaction in case of otitis media in a male infant aged 14 days. $(H$. and $E . \quad \times 290$. $)$ 


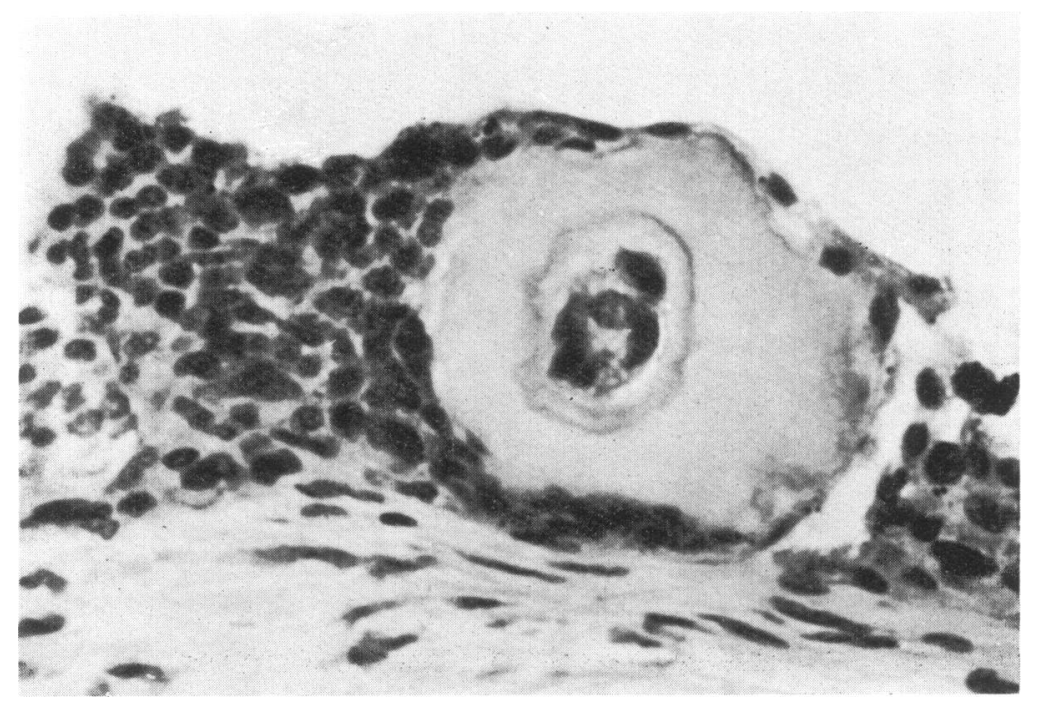

FIG. 7.-Drusen-like nodule in epithelium in middle ear of female infant aged 22 days. $\quad(H$. and $E$.

1163.)

not seen in any stillborn infant, but with increasing age became a fairly common finding. Thus, of the 20 infants over 7 days of age, no fewer than $11(55 \%$ in Fig. 8) had evidence of otitis media.

Gestation and birthweight. The gestation and birthweight of the infants were plotted on the

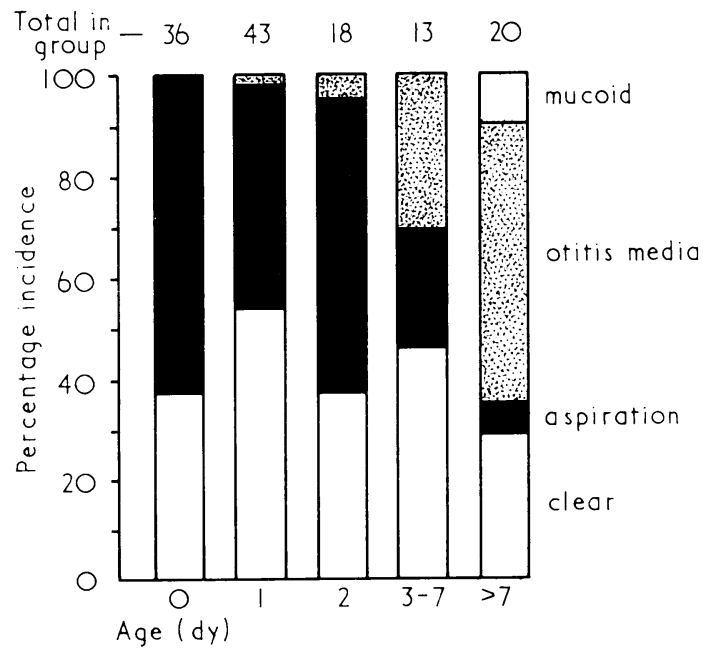

FIG. 8.-Findings in middle ears (mucoid; otitis media; aspiration; clear) related to age of infants. All cases in otitis media group are grouped together; all except 6 cases in the oldest group of infants $(>7$ days) belong to the $P / A$ (purulent exudate) group. grid drawn from the data of Butler and Alberman (1969) (Fig. 9).

Aspirated amniotic debris was rarely seen in infants of 28 weeks' gestation or less, nor was there any case of otitis media among these very immature infants. The distribution of the cases reflects the greater mortality among infants of low birthweight score (Gruenwald, 1969).

Amniotic aspiration. Of the 55 infants in whom aspirated amniotic debris could be shown in the middle ears, 22 infants were stillborn and 19 others died on the first day of life. In the group as a whole, 14 infants were born to mothers who suffered from pre-eclamptic toxaemia (as defined by Butler and Bonham, 1963), 3 of these mothers had an additional complication of bleeding per vaginam in the immediate antepartum period. 16 infants were born after their mothers had had accidental antepartum haemorrhage, 2 were born to mothers suffering from established diabetes mellitus, and in 3 cases there was evidence of isoimmunization to the rhesus blood groups. In 18 cases there was intrapartum asphyxia with fetal bradycardia (heart rate $<100 / \mathrm{min}$ ) where no obvious cause was found, and in 2 cases severe congenital malformations (renal agenesis, transposition of the great vessels) were shown at necropsy. With the exception of the last 2 cases, all the infants in this group were known to have suffered from severe fetal bradycardia before or during labour, in addition to the complications of pregnancy listed. 


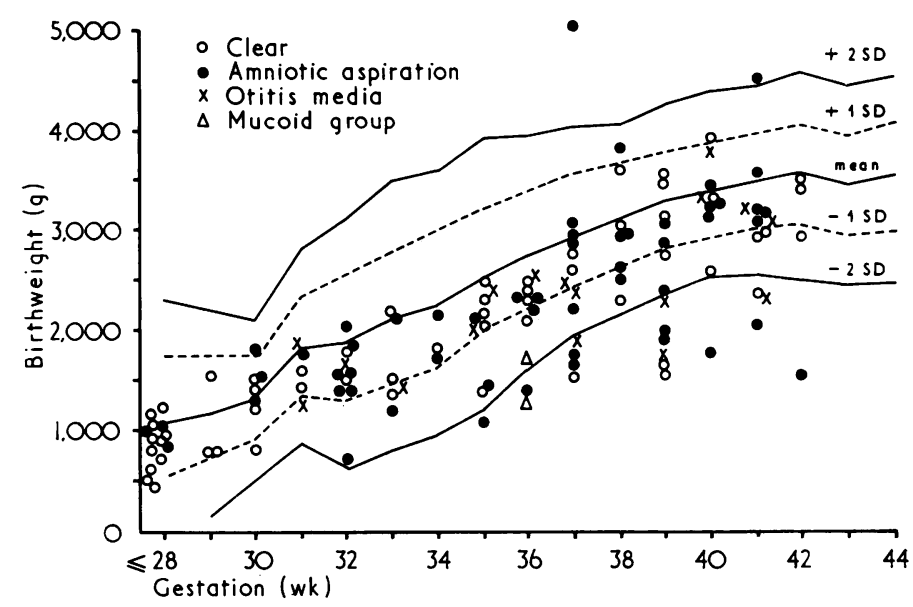

FIG. 9.-Gestational age and birthweight of 130 infants in the present series. The grid shows the mean birthweight and $S D$ s above and below the mean.

Of the infants in the 'aspiration' group, 16 developed respiratory distress syndrome requiring prolonged ventilation, and all died on account of their respiratory problems, with the exception of 2 who had severe intraventricular and paraventricular haemorrhages in the brain, with extensive brainstem petechiae.

With the exception of 5 infants, amniotic debris was readily seen in the lungs of the infants of the 'aspiration' group. In 2 of these 5 cases there was an extensive bronchopneumonia, and the inflammatory exudate may have obscured the presence of pulmonary amniotic debris. In the 3 remaining cases there was evidence of massive pulmonary haemorrhage in 2 and pulmonary hypoplasia in 1.

Otitis media. The main clinical features of the cases with otitis media are summarized in the Table. Cases 1 to 11 represent the cases in the P/A group (exudate of mixed leucocytes and amniotic debris), while Cases 12 to 17 make up the remainder. Certain features deserve additional comment. All the cases of otitis media were associated with evidence of infection elsewhere, particularly with septicaemia, pneumonia, and meningitis. All cases of meningitis occurring in this series of 130 cases were associated with otitis media, and of the 26 cases of bacterial pneumonia, 16 had an associated otitis media.

The cases in the P/A group are notable for the frequency with which a history of prolonged ventilation was present, while this feature does not appear as often in the other cases.

The high incidence of pregnancy complications associated with the cases in the P/A group is similar to the findings in the aspiration group. Cases 13 to 17 , however, appear to be quite different from Cases 1 to 11 with few pregnancy complications and few multiple malformations. Case 12 is of interest in that it has many of the characteristics of the cases in the P/A group, yet no amniotic debris was found on histological examination of the middle ear. Despite this, however, Case 12 stands apart from the other otitis media cases not in the P/A group (cf. Cases 13-17).

It is of interest to see the large number of cases where the infection was due to a Gram-negative organism. In 3 infants the organism responsible was not determined, presumably due to delay in performing the necropsy, to post mortem contamination, to the effects of antibiotic therapy, or to any combination of these factors.

Only in 1 infant (Case 3) was there a history of prolonged rupture of membranes.

Mucoid groups. This was the smallest of all the groups and consisted of 2 cases only. The first case was a male infant born at 36 weeks, weighing $1332 \mathrm{~g}$ who was severely asphyxiated at birth, developed mild repiratory distress from which he recovered, but who had Hirschsprung's disease. He died of peritonitis after a colostomy with bronchopneumonia and 'necrotizing enterocolitis' at 22 days. The second infant was a male born at 36 weeks, weighing $1700 \mathrm{~g}$ after maternal antepartum haemorrhage. He had jejunal stenosis with scattered areas of gut infarction, and developed a severe bronchopneumonia from which he died. 


\begin{tabular}{|c|c|c|c|c|}
\hline Case no. & Sex & Age & Gestation (wk) & Birthweight \\
\hline 1 & $\mathbf{F}$ & $26 d y$ & 31 & 1839 \\
\hline 2 & $\mathrm{~F}$ & $30 \mathrm{hr}$ & 32 & 1680 \\
\hline 3 & $\mathbf{M}$ & $64 \mathrm{hr}$ & 35 & 2400 \\
\hline 5 & $\mathbf{M}$ & $20 \mathrm{dy}$ & 36 & 2480 \\
\hline $\begin{array}{l}6 \\
7\end{array}$ & $\begin{array}{l}F \\
F\end{array}$ & $\begin{array}{r}27 d y \\
4 d y\end{array}$ & $\begin{array}{l}37 \\
37\end{array}$ & $\begin{array}{l}1840 \\
2380\end{array}$ \\
\hline 8 & $\mathbf{M}$ & $7 \mathrm{dy}$ & 39 & 1870 \\
\hline 9 & $\mathbf{M}$ & $22 d y$ & 39 & 2320 \\
\hline 10 & $\mathbf{M}$ & $12 \mathrm{hr}$ & 41 & 3236 \\
\hline 11 & $\mathbf{M}$ & $8 d y$ & 41 & 2300 \\
\hline 12 & $M$ & $9 \mathrm{dy}$ & 31 & 1336 \\
\hline $\begin{array}{l}13 \\
14\end{array}$ & $\begin{array}{c}F \\
M\end{array}$ & $\begin{array}{l}8 d y \\
9 d y\end{array}$ & $\begin{array}{l}33 \\
37\end{array}$ & $\begin{array}{l}1434 \\
2450\end{array}$ \\
\hline 15 & $\mathbf{F}$ & $12 \mathrm{dy}$ & 40 & 3320 \\
\hline 16 & $\mathbf{M}$ & $8 \mathrm{dy}$ & 40 & 3750 \\
\hline 17 & $\mathbf{M}$ & $26 d y$ & 41 & 3060 \\
\hline
\end{tabular}

Cases 1-11 represent the P/A group (exudate of mixed leucocytes and amniotic debris); Cases 12-17 represent the remainder.

\section{Discussion}

Aspiration of amniotic debris and otitis media are not uncommon in newborn infants and the findings of this study are in agreement in many respects with those of Benner (1940). The differences, particularly with respect to her finding true otitis media in stillborn infants, probably represent the better obstetric care now available. Her study is notable in that it stresses the high frequency with which amniotic debris is seen in the middle ears, nasal cavity, and elsewhere. The present study was planned and carried out in ignorance of Benner's earlier work, hence the fact that the nasal and paranasal tissues were not examined.

The present study diverges from that of Benner (1940) also in the interpretation of the sequence of events leading to the development of otitis media. In 16 cases of her series of 70 the placenta was available for examination and in $9(56 \%)$ evidence of chorioamnionitis was found, leading her to believe that aspiration of infected liquor amnii was of prime importance. No case of chorioamnionitis was seen in the 41 placentas available in the present series, even on reassessment. In the one case with otitis media associated with prolonged rupture of membranes (Case 3) the placenta was not available, but even the exclusion of this case would not affect the overall trend of the series. The suggestion that intact fetal membranes may be an ineffective barrier to ascending infection (Bourne, 1962) is difficult to evaluate, since, as shown by Olding (1970), bacterial infection is not likely to be the main cause of chorioamnionitis.

As seen in Fig. 8, aspirated amniotic debris, instead of being cleared rapidly from the airways and the middle ears, may persist for several days and may even excite a reaction akin to that of a foreign body reaction. Here the findings are in agreement 
infants with otitis media

\begin{tabular}{|c|c|c|c|}
\hline Birthweight score* & Complications of pregnancy & Infections other than otitis media & Remarks \\
\hline 0 & Intrapartum asphyxia & $\begin{array}{l}\text { Esch. coli meningitis; } \\
\text { septicaemia }\end{array}$ & $\begin{array}{l}\text { Single umbilical artery; ventilated } \\
\text { from birth for } 28 \mathrm{hr}\end{array}$ \\
\hline 0 & Antepartum haemorrhage & $\begin{array}{l}\text { Ps. aeruginosa pneumonia; } \\
\text { pyaemia }\end{array}$ & $\begin{array}{l}\text { Caesarean section; ventilated for } \\
\text { respiratory distress; } \\
\text { intraventricular haemorrhage }\end{array}$ \\
\hline 0 & Antepartum haemorrhage & $\begin{array}{l}\text { Esch. coli meningitis; } \\
\text { pneumonia }\end{array}$ & Prolonged rupture of membranes \\
\hline 0 & Intrapartum asphyxia & $\begin{array}{l}\text { Pneumonia (organism } \\
\text { uncertain) }\end{array}$ & Ventilated for respiratory distress \\
\hline 0 & Rhesus isoimmunization & $\begin{array}{l}\text { Ps. aeruginosa pneumonia; } \\
\text { pyaemia }\end{array}$ & $\begin{array}{l}\text { Ventilated for respiratory distress; } \\
\text { ligation of patent ductus }\end{array}$ \\
\hline $\begin{array}{l}-2 \\
-1\end{array}$ & $\begin{array}{l}\text { Antepartum haemorrhage } \\
\text { Intrapartum asphyxia }\end{array}$ & $\begin{array}{l}\text { Esch. coli pneumonia } \\
\text { Esch. coli meningitis; } \\
\text { pneumonia }\end{array}$ & $\begin{array}{l}\text { Laryngeal cleft; hydramnios } \\
\text { Caesarean section; ventilated for } \\
\text { respiratory distress }\end{array}$ \\
\hline-2 & Intrapartum asphyxia & $\begin{array}{l}\text { Ps. aeruginosa meningitis; } \\
\text { pyaemia }\end{array}$ & $\begin{array}{l}\text { Caesarean section; ventilated for } \\
\text { fetal distress }\end{array}$ \\
\hline-2 & Intrapartum asphyxia & $\begin{array}{l}\text { Pneumonia (organism } \\
\text { uncertain) }\end{array}$ & Cornelia-de-Lange syndrome \\
\hline 0 & None known & Esch. coli pneumonia & $\begin{array}{l}\text { Hypoplastic left ventricle aortic } \\
\text { stenosis }\end{array}$ \\
\hline-1 & Intrapartum asphyxia & Ps. aeruginosa pneumonia & $\begin{array}{l}\text { Tracheo-oesophageal fistula } \\
\text { corrected; required ventilation } \\
\text { for } 18 \mathrm{hr}\end{array}$ \\
\hline-1 & Intrapartum asphyxia & $\begin{array}{l}\text { Ps. aeruginosa pneumonia; } \\
\text { pyaemia }\end{array}$ & $\begin{array}{l}\text { Ventilated for respiratory distress; } \\
\text { intraventricular haemorrhage }\end{array}$ \\
\hline-1 & None known & Esch. coli pneumonia & Trisomy $13-15\left(D_{1}\right)$ \\
\hline-1 & Intrapartum asphyxia & $\begin{array}{l}\beta \text {-haemolytic streptococcal } \\
\text { empyema }\end{array}$ & $\begin{array}{l}\text { Single umbilical artery; tracheo- } \\
\text { oesophageal fistula; absent } \\
\text { gallbladder; amniotic squames in } \\
\text { airspaces of lungs }\end{array}$ \\
\hline 0 & None known & $\begin{array}{l}\text { Esch. coli meningitis; } \\
\text { ventriculitis; septicaemia }\end{array}$ & $\begin{array}{l}\text { Hydrocephalus; meningomyelocele; } \\
\text { renal papillary necrosis; } \\
\text { bilateral segmental adrenal } \\
\text { necrosis }\end{array}$ \\
\hline 0 & None known & $\begin{array}{l}\text { Ps. aeruginosa meningitis; } \\
\text { septicaemia }\end{array}$ & $\begin{array}{l}\text { Mucoviscidosis; double aneuploidy } \\
47, \mathrm{XXY}, 14-, \mathrm{t}(13 \mathrm{q} 14 \mathrm{q})+\end{array}$ \\
\hline 0 & None known & $\begin{array}{l}\text { Pneumonia (organism } \\
\text { uncertain) }\end{array}$ & $\begin{array}{l}\text { Absent right eye; transposition of } \\
\text { great vessels, diaphragmatic } \\
\text { hernia }\end{array}$ \\
\hline
\end{tabular}

with those of Druss (1932). It could be argued that the metaplastic epithelium and drusen-like nodules (Fig. 2 and 7 ) seen in some older infants may be related to a sterile inflammatory reaction to the presence of aspirated debris. If true, the possible long-term significance of such a sequence of events is intriguing since it is obvious that such areas are devoid of cilia. This may help to explain in part why many survivors of respiratory distress, particularly the more mature infants, have a greater incidence of respiratory infections in the first year of life than would be expected by chance (Lewis, 1968).

No completely satisfactory explanation for the supervention of an acute purulent exudate on the presence of aspirated amniotic debris exists, and it appears that the traditional explanation offered by Benner (1940) is not applicable to the present series. The data in the Table suggest that infants suffering from intrapartum asphyxia who require ventilation are the group most likely to develop otitis media. It must be admitted, however, that it is only a small proportion of infants in this group who go on to develop otitis media. The association of otitis media with ventilation may help explain the relatively large number of cases with Ps. aeruginosa infections (Barson, 1971). It can be argued that stagnant, degenerating organic material could provide a fertile medium for the growth of a secondarily introduced organism. Furthermore, sick newborn infants are far more likely to become colonized by Gram-negative organisms (Davies et al., 1970).

The association of otitis media with neonatal meningitis is of considerable interest, since it is conceivable that earlier anticipation of meningitis may be possible. Unfortunately, routine examination of the tympanic membrane in newborn infants may be hindered by the abundant keratinous 


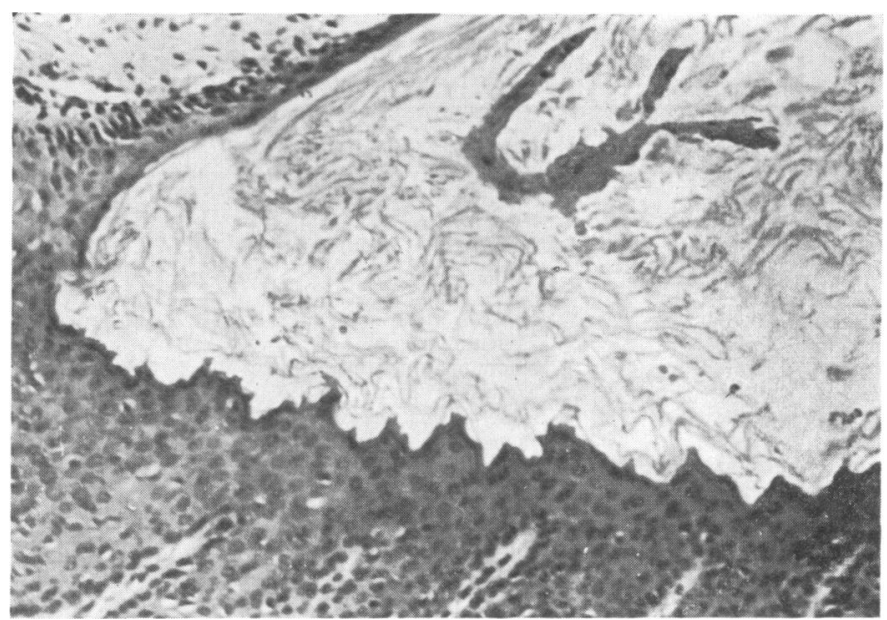

Fig. 10.-Keratinous plugging of auditory canal in Case 6 of Table. (H. and E. $\quad \times 254$.)

plugs in the external auditory meatus (Fig. 10), for these were found in the vast majority of the perinatal cases. The constant association of otitis media with other distant infections, emphasizes that more attention should be paid to examination of the middle ear in neonatal infants when a clinical diagnosis of sepsis is being considered. As suggested by McLellan and colleagues (1962), the role of otitis media in the newborn may be of greater importance than is sometimes thought. The present series suggests that this may be especially relevant in infants requiring ventilation after a delivery complicated by intrapartum asphyxia.

I am grateful for the help of many former colleagues in the Departments of Bacteriology, Pathology, and Paediatrics of the United Oxford Hospitals. Histological sections were prepared by Mr. B. D. Moores and Mr. F. J. Bradley, and the photomicrographs by Dr. T. M. Parry and Mr. D. Luckett.

\section{REFERENCES}

Allen, F. M. B., Morison, J. E., and Rutherford, W. R. (1946) Penicillin in the treatment of neonatal sepsis. Archives of Disease in Childhood, 21, 19.

Barson, A. J. (1971). Fatal Pseudomonas aeruginosa bronchopneumonia in a children's hospital. Archives of Disease in Childhood, 46, 55.

Benner, M. C. (1940). Congenital infection of the lungs, middle ears and nasal accessory sinuses. Archives of Pathology, 29, 455.
Bourne, G. (1962). The Human Amnion and Chorion, p. 175. Lloyd-Luke, London.

Butler, N. R., and Alberman, E. D. (1969). Perinatal Problems, Appendix table 4.2b. Livingstone, Edinburgh and London.

Butler, N. R., and Bonham, D. G. (1963). Perinatal Mortality, p. 303 . Livingstone, Edinburgh and London.

Culling, C. F. A. (1963). Handbook of Histopathological Techniques, 2nd ed., p. 52. Butterworths, London.

Davies, P. A., Darrell, J. H., Chandran, K. R., and Waterworth, P. M. (1970). The efficacy of antibiotics in the neonatal period. In The Control of Chemotherapy, p. 49. Ed. by P. J. Watt. Livingstone, Edinburgh and London.

Druss, J. G. (1932). Infection of the ear in cases of infection of the gastro-intestinal tract in infants. American fournal of Diseases of Children, 43, 356.

Gruenwald, P. (1969). Growth and maturation of the foetus and its relationship to perinatal mortality. In Perinatal Problems, p. 141. Ed. by N. R. Butler and E. D. Alberman. Livingstone, Edinburgh and London.

Lewis, S. (1968). A follow-up study of the respiratory distress syndrome. Proceedings of the Royal Society of Medicine, 61, 771.

McLellan, M. S., Strong, J. P., Johnson, Q. R., and Dent, J. H. (1962). Otitis media in premature infants. Fournal of Pediatrics, 61, 53.

Morison, J. E. (1970). Foetal and Neonatal Pathology, 3rd ed., p. 560. Butterworths, London.

Olding, L. (1970). Value of placentitis as a sign of intrauterine infection in human subjects. A morphological, bacteriological, clinical and statistical study. Acta Pathologica et Microbiologica Scandinavica, Section A, 78, 256.

Correspondence to Dr. D. J. deSa, Department of Pathology: McMaster University, 1400 Main Street West, Hamilton, Ontario, Canada. 